\title{
En moderbunden Prometheus
}

\section{Om Nietzsche, Ernst Bertram og den ny mytologi i Thomas Manns Doktor Faustus}

Thomas Manns Doktor Faustus (1947) er ikke uden grund blevet kaldt en Nietzsche-roman. Af de mange biografier, hvorfra kollagefiguren Adrian Leverkühn henter sine træk, er Friedrich Nietzsches efter alt at dømme den dominerende. Samtidig spiller Nietzsches tanker og deres konsekvenser en central rolle i romanens kultur-, idé- og kunsthistoriske problemkonstellation. I den kulturhistoriske Nürnbergproces, receptionen af Doktor Faustus nødvendigvis udvikler sig til, har man ofte ladet sig friste til i denne tematisering at se en fordømmelse af Nietzsches tænkning, idet man støtter sig til de synspunkter, Mann i tiden omkring romanens skabelse tilbød offentligheden bl.a. med essayet »Nietzsche's Philosophie im Lichte unserer Erfahrung «. Sammen med det diagnosticerende foredrag »Deutschland und die Deutschen« fra 1945 markerer dette humanistiske og demokrativenlige Nietzscheessay måske kulminationen på essayisten Manns afstandtagen fra sin tidligere kulturaristokratiske indstilling, som den blev formuleret i Betrachtungen eines Unpolitischen (1918). Også Doktor Faustus er på den måde blevet læst som led i et Betrachtungen-opgør.

Ligesom Tysklandsforedraget fremviser det kærligt hovedrystende Nietzscheessay med demonstrativ genkendelighed en række af romanens konkrete motiver - ofte i formuleringer, der er noget nær identiske med romanens så det bliver aldeles umuligt ikke at trække tråden fra romanens tematisering til essayistikkens domme. Denne overeksplicitet må selvsagt gøre romanlæseren mistænksom. Jeg vil her give efter for mistroen og undersøge romanens potentiale som andet og mere end den blotte stillen Nietzsche - og beslægtede anticivilisatoriske strømninger inden for tysk kultur - til ansvar for det katastrofiske forløb Adrian Leverkühn og Tyskland gennemgår for øjnene af læseren. Med risiko for at yde ham for megen retfærdighed er ambitionen så at sige at læse romanen med og ikke mod Nietzsche. Til det formål er det nødvendigt at spørge til, hvad - ud over den simple fordømmelse - der kan motivere den forbindelse imellem Nietzschestoffet og ideen om en faustisk djævleforskrivelse, som romanen etablerer ved at lade Nietzsche-klonen 
Leverkühn forskrive sig til djævelen. Hvorfor skal Nietzsche kobles med djævlefiguren? Væsentlige bud på et svar dukker op ved studiet af en ganske særlig Nietzsche-læsning, Ernst Bertrams Nietzsche - Versuch eine Mythologie fra 1918, og af den betydning, den har i Doktor Faustus. Inden jeg når frem til Bertram må der imidlertid foretages en indledende lokalisering af Nietzsches tænkning i romanes problemkompleks, og her bliver det relevant at kigge på romanens tematisering af den bevægelse i tysk kulturhistorie, der går under navnet 'den ny mytologi'.

\section{Den ny mytologi}

Spørgsmålet om den ny mytologi er formentlig mest indgående behandlet af Manfred Frank i de to bind forelæsninger, Der kommende Gott og Gott im Exil. I den sidste af disse forelæsninger, 'Die alte und die neue Mythologie in Thomas Manns Doktor Faustus 6 , inddrager Frank Doktor Faustus i diskussionen, idet han identificerer Leverkühns kunstneriske projekt som et remytologiseringsprojekt. Hvad vil det nu sige?

Remytologiseringsbevægelsen beskrives af Frank som udsprungen af den tyske idealismes desillusion. Allerede hos f.eks. Schelling og Schlegel afløstes den idealistiske optimisme med henblik på at sikre en legitim kulturel samhørighed ud fra den subjektive fornufts almengyldighed ${ }^{1}$, af oplevelsen af en splittelse imellem en maskinel samfundsrationalitet og en analytisk, dvs. opløsende 'Geist'. Hermed diagnosticeredes det borgerlige samfunds legitimationsproblem: »Der mangler, siger Schelling, det bindeled, der ville tillade den analytiske fornuft, som fremmedgør mennesker fra mennesker og atomiserer deres 'Gemeinschaft', at vende tilbage til det absoluttes idé. Under andre betingelser end de, der kendetegner »det borgerlige 'Gesellschaft' ", skal netop et sådant bindeled have »eksisteret i form af mytologien. ii $^{2}$ Frank skitserer, hvorledes denne forestilling om den kulturelle legitimitets afhængighed af myten siden har forplantet sig i den lange tradition for efterlysning af en "mytisk orden«(GIE, p. 335), der med varierende grad af irrationalisme har bevæget sig igennem den tyske romantik, livsfilosofi, ekspressionisme og frem til nazistiske ideologer som Alfred Rosenberg. Da kunstens kultiske potentiale - bl.a. i kraft af forestillingen om den græske tragedie som bærer af en 'umiddelbar socialitet' - fik en central placering i remytologiseringsstemningen, er det relevant for Frank at tale om en æstetiscistisk ideologi: „Er nemlig en gang mytens død gjort ansvarlig for tabet af intersubjektiv forbindtlighed, og er endvidere ... kunstneren blevet udset til at frembringe myten på ny, så lader også Nietzsches forestilling om »der Kunstler-Staatsgrün- 
der« sig aflæse, som ikke blot forekom Hitler så nær, men i det hele taget forklarer den siden romantikken specifikt tyske overbebyrdelse af det kunstneriske arbejde« (GIE, p. 340).

Hvis remytologiseringsbevægelsen kan siges på denne måde at ende i nazismens æstetisering af det politiske, anes ét motiv for romanens - eller med Frank: Zeitbloms - paralleliscenesættelse af Leverkühns og Tysklands historie som en djævleforskrivelse. Franks fremhævelse af Nietzsche som bindeled imellem remytologiseringen og nazismen må således være af særlig interesse for min spørgen til dæmoniseringen af Nietzsche. Når der senere skal arbejdes videre med opfattelsen af Leverkühns ambition som en remytologiseringsambition, skal det ske ud fra en specifikt nietzscheansk formulering heraf. Hvor rationalitetskritikken og efterlysningen af myten i den tidlige romantik stadig formuleredes i idealistiske termer, og måske skal forstås som ønsket om en slags kommunikativ rationalitet - »men denne mytologi må stå i ideernes tjeneste« (GIE, p. 339) hedder det i Das älteste Systemprogram des deutschen Idealismus ${ }^{3}$ - vil det vise sig, at den hos Nietzsche, mere konsekvent, optræder i forbindelse med en tænkning, der forsøger at sætte sig ud over idealismen. Først skal det imidlertid afklares, hvorledes remytologiseringen så afslører sig i Leverkühns projekt.

Den skitserede kulturhistoriske tematik bringes i romanen i forbindelse med det kompositionstekniske i kraft af begreberne 'harmonisk subjektivitet' og 'polyfon objektivitet', som dukker op i forbindelse med Leverkühns lærer Wendell Kretzschmars musikhistoriske forelæsninger i kap. 8. Forestillingen om den harmoniske subjektivitet, knyttet til begrebet om det organiske kunstværk, får her lov at afspejle den borgerligt liberale kulturs ambition om en forenelighed imellem individuel udfoldelse og almengyldig sædelighed. Til grund for en sådan fordring ligger den endnu håbefulde idealismes ambition om de kulturelle værdiers legitimering i henhold til det ideelle og almengyldige. Vor fortæller Zeitblom optræder igennem hele romanen som talsmand for denne humanidealistiske tradition, som løber fra Sokrates over Erasmus af Rotterdam til f.eks. Schiller og videre, og som er forudsætningen for en civilisatorisk kulturforståelse. Heroverfor stiller Kretzschmar den polyfone musiks lovmæssighed, som ikke postulerer nogen harmonisk forenelighed med det enkelte elements udtryksfrihed. Denne forestilling om en polyfoniens mytiske orden angår selve det kompositoriske arbejde, men forbindes samtidig med en vision om geninddragelsen af kunsten i den kultiske praksis: Efter Kretzschmars foredrag diskuterer Leverkühn og Zeitblom: „Gymnasiasten [Leverkühn] viste sig grebet af den tanke, som foredragsholderen slet ikke havde udtalt, men havde tændt i ham, nemlig at kunstens adskillelse fra den liturgiske helhed, dens befrielse og ophøjelse til det ensomt-personlige og 
en kulturel væren formål i sig selv, havde belastet den med en relationsløs højtidelighed, en absolut alvor, en lidelsespatos, der ... ikke behøvede at være dens blivende skæbne, dens stedsevarende sjæleforfatning. ${ }^{4}$ En sådan tankegang må skræmme Zeitblom, som fastholder kunstens status som autonom åndsytring inden for rammerne af en liberal kultur: »»Men alternativet til kulturen er barbariet« afbrød jeg ham. »Med forlov«, sagde han. »Barbariet er kun kulturens modsætning inden for den tankeorden, som kulturen giver os i hænde. Uden for denne tankeorden kan modsætningen være noget ganske andet eller overhovedet ingen modsætning«( $D F$, p. 84). Når Leverkühn kan afvise dikotomien imellem kultur og barbari, vidner det om en kulturforståelse, der radikalt gør op med den civilisatoriske og frem for at forankre den kulturelle samhørighed i en abstrakt almengyldighed, f.eks. i form af rettigheder, søger et substantielt grundlag for kulturen - en mytisk kødelighed. Her berører vi den traditionelle tyske modsætning imellem 'kultur' og 'civilisation', som også skal vise sig relevant i forbindelse med behandlingen af Nietzsche.

Idet han henholder sig til begreberne om harmonisk subjektivitet og polyfon objektivitet, kan Manfred Frank med god ret identificere Leverkühn som remytologiseringsmand: »Leverkühns spørgsmål lyder: hvordan lader polyfonien - det overindividuelle, den mytiske forbindtlighed - sig genvinde under en autonom, men illegitim subjektivitets betingelser?«(GIE, p. 345). I Leverkühns samtale med djævelen i kap. 25 motiveres den kompositoriske remytologiseringsbevægelse ud fra en Adorno-inspireret musikfilosofisk diagnose, hvis konklusion er forkastelsen af den harmoniske subjektivitet og det organiske kunstværk. Med djævelens egne ord: „Påstanden om at det almene kan tænkes harmonisk indeholdt i det særlige, dementerer sig selv. $\star^{5}$ At Leverkühn på denne baggrund kun synes i stand til at komponere parodisk musik, svarer til den splittelse imellem maskinel samfundspraksis og analytisk ånd, som Schelling diagnosticerede. For hvis det organiske værk inkarnerer den idealistiske forestilling om den gensidige bekræftelse imellem individuel udtryksfrihed og formel almengyldighed, hvad er parodien da andet end en skeptisk ånds udstilling af de kunstneriske formers maskinelle sterilitet?

For at overvinde parodiens stadie rejses således kravet om en mytisk orden. Da forestillingen om en organisk orden fordømmes som forløjet 'Schein', må den orden, der fordres, forstås som en magtfuld objektivitets tilsidesættelse af udtryksfriheden, en 'streng sats', og det er dette, Leverkühn tilstræber - bl.a. ved sit konstruktivistiske greb, tolvtoneteknikken. Heraf Leverkühns uvilje over for Zeitbloms opfattelse af kultur og barbari som uforenelige: Den vitalisering af kunsten og kulturen Leverkühn forestiller sig, forudsætter nemlig barbariet, dels forstået som den mytiske objektivitets 
knægtelse af den fri subjektivitet, men måske samtidig - hvis jeg må foregribe mig selv og tage de nietzscheanske termer i anvendelse - som en tragisk vital kulturs indforståethed med det dionysiske kaos.

Djævelens kontraktforslag fremlægges i kap. 25 i forbindelse med forkastelsen af det organiske kunstværk og den harmoniske subjektivitet. Den parodiske musik, Leverkühn er i stand til at komponere, tjener netop til at udstille disse forældede kompositionsprincippers illegitimitet. Det er imidlertid ikke denne virksomhed, der kræver den djævelske inspiration, men derimod bevægelsen ud over det skeptisk parodiske stadie. Det gør djævelen selv klart: »Jeg tror virkelig at djævelen regnes for at være den opløsende kritiks mand. Bagvaskelse - endnu engang min ven! For pokker! Er der noget han hader, hvis noget i hele verden er ham imod, så er det den opløsende kritik. Det han vil og skænker er netop den triumferende sætten sig ud over denne, den prangende hensynsløshed. «" Når Manns roman iscenesætter remytologiseringsbestræbelsen som en djævleforskrivelse, sker det således, idet der lægges vægt på den barbariske frigøren sig fra hensynet. I henhold til den tidligere redegørelse for de idealistiske forudsætninger for forestillingen om harmonisk subjektivitet må der ved denne "prangende hensynsløshed «forstås: hensynsløshed i forhold til den idealistiske fordring om retfærdiggørelse over for det alment gyldige. Betragtningen af et sådant djævelsk tilbud som nietzscheansk inspireret er en af de væsentligste muligheder for at italesætte Doktor Faustus som Nietzsche-roman, på en måde der bevæger sig ud over den blotte konstatering af spidsfindige referencer.

\section{Det mytiske hos Nietzsche}

Manfred Franks inddragelse af Nietzsche som led i remytologiseringsbevægelsen og den æstetiscistiske ideologi sker som bemærket med henvisning til Nietzsches »Entwurf des 'Künstler-Stattsgründers'«(GIE, p. 340) fra Zur Genealogie der Moral. Men måske er det Nietzsches vision om kulturens genfødelse ud af den tyske musiks ånd i Die Geburt der Tragödie og den hævdelse af tysk kultur i opposition til romansk civilisation, som er forbundet hermed, der mest ubesværet er gledet ind i remytologiseringsstemningen. I Tragedie-bogen læser man således: „Ingen skal tro, at den tyske ånd har tabt sin mytiske hjemstavn for evigt, når den stadig så tydeligt forstår de fuglestemmer, som fortæller om denne hjemstavn. $\|^{7}$

Nietzsche formulerer sin vision på baggrund af en analyse af den religiøsitet, som han finder udtrykt i den græske tragedie. Analysen bygger på begreberne om det 'dionysiske', erfaringen af alle identiteters sønderrivelse i 
livsviljens 'ur-ene', og det 'apollinske', den formgivende illusions transfiguration af det kaotiske. Angående forholdet imellem disse to principper når Nietzsche frem til følgende konklusion: „Dermed viser den apollinske illusion sig som det, den er, som en kun i tragediens tidsrum bestående tilsløring af den egentlig dionysiske virkning: som dog er så kraftfuld, at den til slut kan drive selve det apollinske drama ind i en sfære, hvor det begynder at tale med dionysisk visdom, og hvor det negerer sig selv og sin apollinske synlighed. $\mathrm{Og}$ således kan det vanskelige forhold mellem det apollinske og det dionysiske i tragedien symboliseres som en broderpagt imellem de to guddomme« $(G T$, pp. 139-40). Der bliver altså tale om en dynamik imellem det illusionsskabende og det illusionsopløsende: det apollinske 'Schein' vinder sin vitalitet sin 'dionysiske visdom' - ved at se det dionysiske kaos i øjnene og lade sig gennemstrømme af livsviljen. Når det mytiske anbefales hos Nietzsche, er det som organ for kulturens bekræftende dyrkelse af denne vekselvirkning.

Nietzsches begejstrede udlægning af det tragiske står side om side med fordømmelsen af den rationelle og menneskeforbedrende idealisme - repræsenteret af Sokrates - som årsagen til den græske kulturs forfald. Den idealistiske tænknings elendighed består i, at den i sin orientering imod det evigt og alment gyldige hinsides ikke er indforstået med illusionsdynamikkens strøm, som præmis for kulturel værdiskabelse: Ambitionen om at legitimere værdierne i henhold til en illusorisk idealitet forhindrer en »Bejahung « af den faktisk levende illusion. Det er uviljen over for en sådan forholden sig til en transcendent retfærdiggørelseshorisont, der er baggrunden for Nietzsches vedvarende angreb på idealisme og kristendom.

Til forskel fra den jødiske og kristne monoteismes abstrakthed giver den mytiske religiøsitets kødelighed mulighed for konstant bejaelse og nedrivning af gudebilleder. Prometheus, der hos Nietzsche omtales som både maske for Dionysos og efterkommer af Apollon, kan forstås som inkarnationen af denne aktivitets dobbelthed: I den formastelighed, hvormed Prometheus antaster den guddommelige instans - han tilraner sig som bekendt det guddommelige privilegium at give liv til mennesker - viderefører han netop det guddommelige aristokratis vitalitet. Nietzsches kulturaristokratiske indstilling skal således ikke forstås som et konservativt ønske om fastholdelse af gamle værdier, men som en insisteren på de livskraftige individers privilegium - på vigtigheden af, at de, der magter at konfrontere det dionysiske og skabe ud af dets kraft, kan udfolde sig uden hensyn til det krav om almengyldig retfærdiggørelse, som er fundamentet for enhver demokratisk indstilling.

Nietzsches illusionsvitalisme synes altså at hænge sammen med den indifferens i forhold til det idealistiske retfærdiggørelsesbehov, jeg har identificeret som kernen i djævelens tilbud til Leverkühn. »Uden myte«, skriver Nietz- 
sche, "mister enhver kultur sin sunde skabende naturkraft: Først en af myter omkranset horisont afrunder en hel kulturbevægelse til en enhed. $\aleph^{8}$ Med dette billede af den omkransende myte gives et indtryk af, hvorledes den for at sikre kulturens vitalitet så at sige skal afskære udsynet til transcendensens retfærdiggørelseskrav.

Med referencen til Zur Genalogie der Moral forholder Manfred Frank sig til en noget senere Nietzsche, som har ændret sin indstilling til en række af de konkrete kulturfænomener, der fæstedes lid til i debutbogen: Richard Wagner, den tyske musik, reformationsånden og selve Tysklands anlæg for det mytiske. Hvis man fokuserer på illusionsvitalismen og den kulturaristokratiske tankegang, kan der dog være grund til at fastholde kontinuiteten imellem Tragedie-bogen og den senere tænkning. I beskrivelsen af »des 'KünstlerStaatsgründer" "genfinder man således fremhævelsen af den vitale skaberkrafts uanfægtethed: „De ved ikke hvad skyld, hvad ansvarlighed, hvad hensyn er, disse fødte organisatorer; i dem råder denne frygtindgydende kunstner-egoisme, der glitrer som malm og - ligesom moderen i sit barn - forlods ved sig evigt retfærdiggjort i 'værket'. «"

Remytologiseringen er en sammensat bevægelse ${ }^{10}$, men sådan som Frank skitserer den, dvs. som voksende ud af den tyske idealismes desillusion, synes dens mest konsekvente formulering at være en nietzscheansk illusionsvitalisme. Under alle omstændigheder er det oplagt at identificere Nietzsches forestilling om en aristokratisk uskyld med den "prangende hensynsløshed", der er substansen i det djævelske tilbud, og som skal føre Leverkühn ud over den parodiens desillusion, der er resultatet af mistilliden til det organiske kunstværk og postulatet om harmonisk subjektivitet. Rent kompositionsteknisk er denne bevægelse hos Leverkühn knyttet til den tolvtoneteknik, jeg tidligere har omtalt som konstruktivistisk. Hvor det organiske værk implicerer illusionen om den gensidige retfærdiggørelse imellem det enkelte og det almene, indebærer det konstruktivistiske værk opstillingen og bejaelsen af den kunstneriske illusion i al dens arbitraritet, i al formens illegitime dominans over det individuelles udtryksfrihed. At fremvise formernes arbitraritet er også parodiens ærinde, men dette på en sådan måde, at den manglende legitimering skinner i øjnene, hvorved legitimeringen for så vidt stadig synes at være det parodiske værks anliggende, ligesom en nok så desillusioneret og desperat idealisme stadig må kaldes idealistisk. En konstruktivisme hinsides parodien må derimod karakteriseres ved, at den arbitrære form præsenterer sig med så stærk en selvbejaende udstråling, at spørgsmålet om retfærdiggørelse bliver ligegyldigt. Som Prometheus må kunstneren opstille sig selv som guddommelig instans, og ud af egen suveræn skaberkraft puste liv i materialet. En konstruktivisme hinsides parodien må fremstille de kunstneriske 
former som suveræne i deres illegitimitet. Leverkühn kan nok selv udtænke sin tolvtoneteknik, men til at opnå denne triumferende ignorans over for transcendensens altid krævende retfærdiggørelseshorisont er djævelens hjælp øjensynlig nødvendig, eller som det hedder i komponistens slutmonolog: "»Den som vil vælte kegler må først stille dem op, og i dag må man tye til dieffuelen, eftersom man ingen anden kan bruge og få til store gerninger og værker end hannem«(DF, p. 657).

Men hvorfor denne iscenesættelse af den nietzscheanske remytologiseringstanke som djævelskab? Leverkühns remytologiseringstanke er indforstået med barbariet, og ud fra et civilisatorisk synspunkt - som Zeitbloms må det derfor synes lige til: Tilsidesættelsen af retfærdiggørelseskravet må stå som den største uretfærdighed og fortabelse. Derfor er der tale om en djævleforskrivelse. At fælde en sådan dom synes måske ikke mindre oplagt, efter man af Manfred Frank er blevet gjort opmærksom på, hvorledes remytologiseringsbevægelsen ender i den nazistiske ideologi og således den tyske katastrofe. ${ }^{11}$ Med denne fordømmende udlægning har man imidlertid ikke opnået andet end at nægte at gå ind på den nietzscheanske kulturkritiks præmisser. Hvis Leverkühns hensynsløshed skal forstås i nietzscheanske termer, altså som udtryk for det vitale menneskes selvbekræftelse i indforståetheden med den dionysiske afgrund, må det vække opsigt, at denne vitalitet i Manns roman iscenesættes som inspiration fra en instans i det teologiske verdensbillede. Måske er det ikke bare udtryk for en simpel fordømmelse, når Nietzsches prometheiske formastelighed hos Mann bliver til djævelskab, når den aristokratiske uskyld - De ved ikke hvad skyld ... er« - kobles med den figur, der frem for alt symboliserer menneskelig skyld, og der således antydes en forståelse af illusionsvitalismen - og efterlysningen af myten - ud fra en kristen transcendensorienterings logik, som den netop forsøger at overvinde. For at blive klogere på, hvad djæveleskikkelsens optræden i det hele taget handler om, er det nødvendigt at kigge på, hvorledes Nietzsche-materialet har fundet vej til Doktor Faustus. Her kommer Ernst Bertrams Nietzsche - Versuch eine Mythologie ind i billedet.

\section{Bertrams Nietzsche}

Bertrams Nietzsche-monografi er helt central for receptionen af den tidlige Nietzsches håbefulde formuleringer om den tyske kulturs fortrinligheder. Bertrams vilje til at læse Nietzsche som tysker er så stor, at hans bog hos Bernhard Böschenstein, der mest udførligt har gjort opmærksom på Bertrams betydning for Doktor Faustus, må omtales som »en samlet betragtning 
af en tysk Nietzsche og et nietzschesk Tyskland. « ${ }^{12}$ Bestemmelsen af det tyske samler sig om ideen om »das deutsche Werden«, det tyske væsens karakter af stadig uforløst tilblivelse, med andre ord dets faustiske stræben. Central for Bertrams forståelse af Nietzsche er endvidere forestillingen om den tyske kulturs musikalitet, som den forstås i modsætning til den europæiske civilisations lidenskabsløse prosa. Det er måske først og fremmest denne idé om den tyske musikalitet, der har udgjort kernen i det åndsbroderskab, som angiveligt herskede imellem Bertram og den unge Mann, forfatteren til Betrachtungen eines Unpolitischen. Idet han tager udgangspunkt i det konstaterede slægtskab mellem Bertrams tankegang og den anticivilisatoriske indstilling, Mann havde givet udtryk for, kan Böschenstein operere med den tese, at Mann ved sidenhen at indoptage og dermed problematisere Bertramstoffet i Doktor Faustus implicit gør op med sin egen tidligere position. Som jeg håber at nå frem til, kan der dog være grund til at pege på væsentlige uoverensstemmelser imellem Bertrams og Betrachtungens nietzscheanisme.

Hos Böschenstein opregnes en lang række motiver fra Bertrams karakteristik af Nietzsche, som går igen i Manns roman - primært motiver, der indgår i iscenesætttelsen af selve Leverkühn-figuren. Af disse vil jeg her fremhæve tre indbyrdes forbundne træk, som kan placeres under overskrifterne: inderlighed, sygelighed og koblingen af Nietzsche med Albrecht Dürer og Martin Luther. Inderligheden - svarende til den tyske inderlighed, Mann kritiserer i Deutschland und die Deutschen - dukker hos Bertram op i identifikationen af Nietzsche med det tysk musikalske sindelag, der indebærer en ligegyldighed over for sociale anliggender: »thi den gode musiker er altid eneboer og 'uden for tiden’. «13 Dette træk er håndgribeliggjort i Leverkühns kølige asocialitet, den spekulative munks ensomhed. Sygelighedsmotivet knytter sig til forestillingen om en nødvendig forbindelse imellem sygdom og kunstnerisk kreativitet. Ifølge Bertram lader Nietzsches geni sig ikke skille fra hans galskab og mulige syfilis, to lidelser der går igen hos Leverkühn. Hvad angår Bertrams gennemgående identifikation af Nietzsche med Luthers og Dürers reformationsånd, som inden længe skal undersøges nærmere, har også denne på talrige måder sat sit aftryk i Doktor Faustus. ${ }^{14}$ Disse træk ved Bertrams Nietzsche-billede har som sagt været centrale for romanens konstruktion af Leverkühn-figuren. For forståelsen af det følgende vil det være afgørende at opretholde et skel imellem dette begreb om Leverkühns figur og begrebet om hans projekt.

Jeg har tilladt mig at omtale kernen i Leverkühns remytologiseringsprojekt, den illusionsvitalistiske tilstræbelse af en "prangende hensynsløshed», som afskærelsen af udsynet til transcendensen. Hos Bertram gør man sig nu den interessante iagttagelse, at de mange motiver af betydning for Lever- 
kühn-figuren samles i noget, der ligner en totallæsning af Nietzsches liv og værk som udtryk for netop en kompromisløs transcendensorientering. Dette skinner igennem i inddragelsen af Nietzsche i ideologien om 'das deutsche Werden', »den ægte tyske hjemlængsel« (NVM, p. 91), hvorom det hedder: „Det tyske væsen føler sig, oplever sig selv som en åndens puppetilstand, som usamtidighed og vækst, som fjendtlig uopnåelighed og uhyre forhåbning « ( NVM, p. 79). Tankegangen indebærer en stadig mistro over for enhver tilsyneladende forløsning af denne "uhyre forhåbning'. "En tyskhed, der tror sig ved målet, der forestiller sig at have opnået sin legemliggørelse (sin 'kultur'), er for ham [Nietzsche] intet andet end en vederstyggelig forvrængning" (NVM, p. 97) .

Det er i kraft af denne overraskende bestemmelse af en uvilje over for kødeliggørelsen hos Nietzsche, at Bertram kan hævde hans slægtskab med den lutherske kristendom, der i og med opgøret med den katolske kirkelighed gør troen til individets håbløse, men heroiske kamp: $0 \mathrm{Og}$ Nietzsches misforståelse af sig selv som antikristen er et ligeså gyldigt udtryk for denne nordiske kristelighed (omend ikke kirkelighed) som den antipapistiske bondekraft hvormed Luther sønderbrød den 'romerske' middelalder« (NVM, p. 68). Nietzsche skulle angiveligt have afvist romerkirkens institutionaliserede kristelighed for dybest set at tilslutte sig Luthers inderliggørelse af det religiøse, „denne skæbnesvangre 'protestantiske' isolering af individet hvorom Luther engang udtalte de tappert renoncerende ord: "Jeres liv er et ridderskab«" (NVM, p. 56-57). De angreb på Luther, som Nietzsche - efter tragediebogens venlige omtale af den tysk-reformatoriske ånd - sætter ind med, ignorerer Bertram ikke, men ligesom det er tilfældet med Nietzsches kritik af romantikken, af Wagner, af Tyskland og dets musikalitet, kort sagt af hele 'Sehnsucht'-mentaliteten, uskadeliggøres udfaldene mod lutherdommen, idet de udlægges som et broderfjendskab, der blot bekræfter broderskabet og samtidig 'das deutsche Werden', det stadige selvopgør.

Noget kunne tyde på, at man i Doktor Faustus finder en tematisering dels af Nietzsche, dels af Bertrams Nietzsche, og at det vil kunne betale sig at spørge til forholdet imellem disse to. Manns skildring af den remytologiseringsstemning, der gennemsyrer det tyske åndsliv i Leverkühns levetid, er domineret af nietzscheansk tankegods. Foruden Leverkühns projekt gælder det f.eks. den magtfilosofiske dyrkelse af 'den stærke illusion', som til Zeitbloms bekymring udfolder sig i den såkaldte Kridwiss-kreds, og det gælder Chaim Breisachers kritik i kap. 28 af almen- og dermed abstraktgørelsen af guddommen og forfladigelsen af det religiøse til etik og "human vandsuppe» (DF, p. 379). Begge disse ytringer konkretiserer uviljen over for det idealistiske hensyn til det almene, og efterlysningen af en slags kødeliggørelse af 
kulturen, og knytter sig således til Leverkühns ambition om at opnå en konstruktivisme hinsides parodien. I tegningen af Leverkühn-figuren trækker Mann imidlertid på Bertrams særlige Nietzsche-reception, der placerer sig i strid modsætning til den illusionsvitalistiske remytologiseringstanke.

Den tyskhed, der hos Nietzsche hyldes for dens mytiske forankring, fremtræder hos Bertram primært som en kultur defineret ved den rene trods over for det øvrige Europa: Bertrams alternativ til den civilisatoriske abstrakthed udgøres af myten om 'der deutsche Werden', altså fornægtelsen af enhver mytisk kødeliggørelse, til fordel for den evige længsel. Hvor Nietzsche som forudsætning for den vitale kultur taler om, hvorledes myterne må afskærme blikket udad - »en af myter omkranset horisont« (GT, p.145) - har den ægte tysker hos Bertram sit blik rettet mod transcendensen: tyskeren må hele tiden overvinde sig selv. I denne ånd holder Bertram sig ikke tilbage fra at tænke tragediens Grækenland, hvori Nietzsche finder forbilledet for overvindelsen af idealismens transcendensorientering, som en utopisk horisont for den tyske rastløshed - hvilket netop formuleres i idealistiske termer: »Hellas er en 'tyskere' Tyskheds platoniske idé« (NVM, p. 99). Det synes som om Bertram - i en særlig heroiserende tone - lægger stemme til netop den desillusionerede idealisme, Nietzsches værk kan ses som et forsøg på at bevæge sig udover. Endvidere kan man registrere, at denne den sene idealismes oplevelse af illegitimitet nu optræder i form af en luthersk syndsbevidsthed.

Remytologiseringsprojektet må formuleres som ambitionen om at sætte sig ud over det idealistiske retfærdiggørelsestryk, dvs. afskære udsynet til transcendensen, men iscenesættes i Doktor Faustus i de klæder og kulisser, som Bertrams transcendensorienterede udlægning har påført Nietzsche. Det er på baggrund af dette forhold, man må forstå romanens sætten Nietzsche i forbindelse med djævleforskrivelsen og derved en kristen syndsbevidsthed. Efter alt at dømme bliver det djævelske først relevant, idet Nietzsche i Leverkühn smelter sammen med Luther-skikkelsen og den protestantiske heroisme - og det er netop formidlingen af denne kontakt, Bertram repræsenterer. Den permanente uforløsthed, som definerer den lutherske ridderlighed - fornægtelsen af enhver selvretfærdiggørelse - ytrer sig nemlig som et personligt forhold til djævelen, dvs. som en stadig syndsbevidsthed. Som sit foretrukne billede på den nord-kristne heroisme bruger Bertram således Dürers snit 'Ritter, Tod und Teuffel' - som skulle have været blandt Nietzsches kæreste ejendele - og i denne anvendelse tjener djævleskikkelsen netop til at bekræfte omfanget af den kristendoms styrke, som kun vil sin egen uforløsthed - eller med Bertrams egne ord: "... det mod der ikke skyr det frygtelige, døden, heller ikke det betænkelige, djævelen, men derimod søger det, bejaer det, vil det« (NVM, p. 58). Ud fra Bertrams tankegang kan syndsbevidsthe- 
den kun virke bestyrkende på den tyske heroisme, eftersom den sikrer, at transcendensorienteringen aldrig kompromitteres.

Når Mann bruger djævleskikkelsen, refererer det selvsagt til hele Fausttraditionen, men hvis det er Nietzsches rolle i romanen, det drejer sig om, er det nok frem for alt i referencen til Bertrams inddragelse af Nietzsche i sammenhæng med en luthersk bejaelse af egen syndighed, at djæveleskikkelsen får sin betydning. Således kan han i kap. 25 - og med hentydning til Luthers berømte blækhuskast - lade djævelen omtale reformatoren som »Doktor Martinus ..., der stod på en så djærv og hjertelig fod med mig« (DF, p. 313). Snarere end Nietzsches illusionsvitalisme er det måske koblingen af den nietzscheanske formastelighed med denne lutherske inderligheds 'verkörperung'fjendskhed og det radikalt ukonstruktive kulturbegreb, som følger heraf, der iscenesættes som diabolsk i romanen.

Sammensmeltningen af Nietzsche og Luther billedliggør infiltrationen af livsfilosofien i teologien. Denne udvikling - som Zeitblom skeptisk gør rede for i forbindelse med beretningen om Leverkühns teologiske studier i kap. 11 - synes motiveret af den utilfredshed med den liberal-teologiske reduktion af det religiøse til humanistisk etik, som f.eks. Breisacher giver udtryk for, og som er fundamental for remytologiseringsbevægelsen. »Den civiliserede menneskeånd«, skriver Zeitblom, "man kalde den så borgerlig eller lade den blot gælde som civiliseret, kan ikke undgå en følelse af noget uhyggeligt herved. Thi når teologien bringes i forbindelse med livsfilosofiens ånd, med irrationalismen, løber den ifølge sin natur en risiko for at blive til dæmonologi« $(D F$, pp.126-27). På samme måde må koblingen af Nietzsche med Luther føre til djævelskab. Men bekymringen over alliancen imellem teologi og livsfilosofi er ikke udelukkende Zeitbloms civilisatoriske humanismes - som nævnt, er baggrunden for udviklingen netop humanismens dominans i og med den liberale teologi. Bekymringen må også formuleres ud fra en nietzscheansk vitalismes synspunkt, der ikke kan bryde sig om, at dens prometheiske uanfægtethed transformeres til forelskelse i anfægtelsen, i den menneskelige skyld. Den vitalistiske remytologiserings ambition om at sætte sig ud over idealismens retfærdiggørelsestryk lader sig ikke gennemføre - og fører tilsyneladende til kulturelt hysteri - hvis remytologiseringstanken fra begyndelsen er skrevet ind i en tyskheds-dyrkelse, der er gennemsyret af transcendenserfaring og syndsbevidsthed. Visionen om en "prangende hensynsløshed« er altid allerede kastreret, hvis den udtales af djævelen. Således må Leverkühns nietzscheanske projekt - bestræbelsen på at nå et suverænt udtryk - mislykkes, fordi hans fatale figur er inficeret af bertramsk syndsbevidsthed. 


\section{Faldet $i$ moderskødet}

Må kernen i djævelens tilbud identificeres som den illusionsvitalistiske ignorans i forhold til transcendensens retfærdiggørelsesfordring, er den kendsgerning, at det er djævelen, der tilbyder, udtryk for, at denne hensynsløshed ikke desto mindre ved skylden er fanget under gudsinstansens bebrejdende blik. Den djævelske formastelighed er uadskillelig fra syndsbevidstheden, som Bertrams protestantiske ridder drives den ligefrem deraf. Denne logik skærer romanen ud i pap ved at lade det fremgå, hvorledes Leverkühns første skridt ind i djævleforskrivelsen, hengivelsen til Esmeralda, netop, som perversitet, animeres af hendes advarsel ( $D F$, p. 209), hvilket får lov at spejle den i romanen nærværende tanke, at Adam og Evas bid af æblet motiveredes af forbudet selv. ${ }^{15}$ Da det er hos Esmaralda, at Leverkühn pådrager sig syfilis, er sygelighedsmotivet og derved Leverkühns kreativitet uadskilleligt fra syndefaldsmotivet. For Bertram er den lutherske syndefaldserfaring indbegrebet af Nietzsches nord-kristne heroisme, men for den remytologiseringstanke, jeg har fremhævet, betyder den undergangen.

Som immanensens syndighed er den djævelsk inspirerede vitalisme underordnet det teologiske perspektiv. Leverkühns remytologiseringsidé viser sig således fra begyndelsen at have været indskrevet $i$ hans teologiske engagement. Første gang Leverkühn formulerer behovet for en 'mytisk orden', sker det eksempelvis under henvisning til Paulus. Zeitblom citerer: »»Orden er alt. Romerbrevet det trettende: »der er ikke orden uden af Gud.« Han rødmede, og jeg så på ham med store øjne. Det viste sig, at han var religiøs« $(D F$, pp. 63-64). Hidtil har jeg lagt vægt på tekststeder, hvor Leverkühns konstruktivisme præsenterer sig som bestræbelsen på at opnå den arbitrære forms suverænitet, men nu bliver det relevant at henlede opmærksomheden på de steder, hvor en forbindelse antydes imellem Leverkühns konstruktivisme og så talmystikken og det allegoriske konstellationsarbejde, hvis dynamik drives af transcendensorienteringen. ${ }^{16}$ Det mest håndgribelige fingerpeg i retning af talmystikken er det 'magiske' talkvadrat, komponisten har hængende over klaveret på sit kammer i Halle, »et såkaldt magisk kvadrat af den slags, der ved siden af timeglasset, cirklen, vægten, polyederet og andre symboler også ses på Dürers 'Melancholia' «(DF, p.129).

Parallelt tilbyder der sig altså igennem romanen to konkurrerende forståelser af Leverkühns konstruktivistiske opgør med det organiske kunstværk og den harmoniske subjektivitet: der er tale om en stræben efter suveræn transcendensglemsel knyttet til en nietzscheansk remytologiseringenstanke, og der er tale om en slags allegorisk praksis som udtryk for syndefaldsbevidsthedens melankoli. ${ }^{17} \mathrm{Og}$ når Dürers melankolien mod slutningen synes at 
få overtaget - hvilket giver sig udtryk i en voksende forekomst af barokt inventar i romanens referencemaskineri - sker det i takt med, at remytologiseringsprojektets falllit træder tydeligt frem. Dürer-Tyskland og den lutherske ånd, Kaisersaschern-ånden, demonstrerer sit solide greb om Leverkühn: „Gav Kaisersaschern ham nogensinde fri?« spørger Zeitblom, »Tog han den ikke med sig, hvor han end gik, og blev han ikke bestemt af den, skønt han altid mente selv at bestemme? ... Adrian Leverkühn og denne by - jo, visselig, tilsammen resulterede dette i teologi« $(D F$, p. 117)

Den rekonstruktion af udtrykket, som Leverkühn ifølge Zeitblom når frem til i sit sidste værk Dr. Fausti Weheklag, fremtræder således ikke som opnåelsen af den "prangende hensynsløshed«, som djævelen tilbyder, men som en genfødelse af udtrykket i det faldne menneskes klagesang: »[...] hvad hvis den kunstneriske paradoksi, at udtrykket - udtrykket som klage - fødes ud af den totale konstruktion, skulle svare til det religiøse paradoks, at der af den dybeste fortabelse, omend kun som det sagteste spørgsmål, spirer et håb? «18 I en sådan tolkning opnår den konstruktivistiske demonstration af konstruktionens illegitimitet sit 'Durchbruck', ikke i en vitalistisk fornægtelse af retfærdiggørelseskravet, men som fortvivlet syndsbekendelse og hengivelse til Guds paradoksale nåde.

Som remytologiseringsprojekt var Leverkühns bestræbelse på at nå en musik hinsides parodien at forstå som bestræbelsen på at sætte sig ud over den desillusionerede idealismes kvaler i forhold til legitimeringen. Nu fremtræder altså kulminationen af Leverkühns værk, genoptagelsen af den barokke Lamento, ${ }^{19}$ som udtryk for samme erfaring af illegitimitet, men omfortolket ud fra den lutherske doktrin om, at menneskets eneste retfærdiggørelse ligger i anerkendelsen af, at det ikke kan retfærdiggøres ved sig selv, men kun ved nåden. ${ }^{20}$ Denne logik forklarer 'Weheklag's såkaldte tolvtoneord, »Denn ich sterbe als ein böser und guter Christ« (DF, p. 647), knyttet til tonerne h-e-a-e-es (Hetaera Esmeralda) og derved til erindringen om Leverkühns personlige besmittelse og fald. Sætningen formuleres i 'Weheklag' af den fordømte Doktor Faustus, der i en scene svarende til Leverkühns eget afskeds- og bekendelsesselskab, må værge sig imod de humanoptimistiske pårørendes forsøg på at vinde ham for denne verden: »... ikke kun af formel troskab mod pagten, og fordi det er »for sent«, men fordi han foragter positiviteten i den verden, som man vil redde ham til, dens gudeligheds løgnagtighed, af sin ganske sjæl«(DF, p. 649). Som menneske er Faustus falden, men dog, i modsætning sine pårørende, en god kristen i opgivelsen af enhver menneskelig retfærdiggørelse. 
Udtrykket rekonstrueres altså i klagen, og den nietzscheanske substans i Leverkühns forskrivelse til djævelen træder således i baggrunden for den syndsbevidsthed, der udtrykkes i selve djævleskikkelsen. At Leverkühn som reaktion på Nepomuks død - den definitive demonstration af inkarnationens umulighed - erklærer sin officielle tilbagetagelse af Beethovens 9. symfoni og dermed Schillers optimisme, virker som en tekstintern anakronisme; denne tilbagetagelse har hele tiden været præmissen for hans kunstneriske projekt. Det, der på dette trin af romanens forløb annulleres, er ikke primært humanidealismen, men selve troen på menneskelig værdi og enhver betragtning af mennesket som andet end faldent. Tilbagetagelsen gælder ikke mindre remytologiseringen og bestræbelsen på at hævde en suverænitet.

Som Ikaros falder remytologiseringsprojektet til jorden. Således kan Zeitblom gruble over synet af Leverkühn, som denne efter sit fald befinder sig i barndomshjemmet, opslugt af moderhavets omsorg: „For en moder er heltesønnens Ikarosflugt, den brat stigende mandsgerning, der øves af den, som er vokset fra hendes omsorg, i grunden en ligeså syndig som uforståelig forvildelse, af hvilken hun altid med hemmelig krænkelse hører det fremmede og åndeligt strenge »Kvinde, hvad har jeg med dig at gøre!« og den faldne, tilintetgjorte, det "stakkels, kære barn« tager hun fuldt tilgivende tilbage til sit skød med den forvisning, at han havde gjort bedst i aldrig at frigøre sig derfra. $«^{21}$ For Leverkühns vedkommende kan det imidlertid konstateres, at moderfavnen ikke på noget stadie har sluppet taget i ham. Han synes igennem sin manddom at være styret af moderlængsel. Dette kommer tydeligst til udtryk i valget af Schweigestills gård - med dens udpenslede lighed med barndomshjemmet - som rammen for hans væsentligste arbejde, og i den angivelige forelskelse i Marie Godeau, hvis sangstemme er så lig moderens. ${ }^{22}$

Den moderlige fatalitet gør sig altså gældende $\mathrm{i}$ forbindelse med alle romanens vigtigste kvinder og klinger således også med i Esmaralda-figurens fatalitet og den musik, hun bogstaveligt talt prædeterminerer via tonekonstellationen: h-e-a-e-es. I beskrivelsen af dette motivs funktion fremtræder Leverkühns konstruktivisme på en gang som et udtryk for allegorikerens almagt og hans skæbnebestemthed: tallenes arbitraritet og tallenes magt. Men hos Leverkühn hænger fatalitet og den syndefaldserfaring, som stimulerer arbejdet med tallene, også sammen. Hans skæbne er netop bestemt af blikket mod transcendensen. Det er den lutherske syndsbevidsthed, lystens perverse afhængighed af forbudet, der slynger ham i armene på Esmaralda og dermed djævelen.

Hos Bertram så vi kærligheden til moderlandet som uadskillelig fra den romantiske higen - det ædle ved det tyske var uforløstheden - ligesom hans transcendensorientering, »den ægte tyske hjemve« (NVM, p. 91), fremtræder 
som en besættelse af en tabt idealitet i stil med moderskødet. Tilsvarende læser jeg her moderfavnens magt som syndsbevidsthedens magt, der kommer til udtryk i romanslutningens generelt omsiggribende melankoli, og som for remytologiseringen, i det omfang den forstås nietzscheansk, må indebære kastration. For den faldne Leverkühn, der har lagt først humanidealismens ambition om retfærdiggørelse og dernæst det vitalistiske forsøg på at sætte sig ud over retfærdiggørelsesbehovet bag sig, resterer den moderligt omklamrende nåde ${ }^{23}$ som eneste forløsningsmulighed.

\section{En nietzscheansk kulturkritik}

Ud fra ambitonen om at forklare romanens kobling af Nietzsche med det djævelske som udtryk for andet end en simpel fordømmelse har jeg spurgt ikke blot til, hvorledes Nietzsche bryder med den idealistiske præmis, dvs. retfærdiggørelseskravet, men hvorledes den nietzscheanske præmis i Manns roman brydes, så der kan blive tale om en djævlepagt - altså hvorledes Nietzsches prometheiske uskyld bliver til djævelskabens uendelige skyld. Både tematisk og tekstgenetisk set er studiet af Ernst Bertrams Nietzsche-reception afgørende for forståelsen af denne transformation. Idet Bertram i forbindelse med udsyngelsen af sin hyldest til 'das deutsche Werden' sammentænker Nietzsche og den lutherske heroisme, bringes djævelen på banen. Leverkühns projekt kunne identificeres med den vitalistiske bestræbelse på at afskære udsynet til den bebrejdende transcendens. Som figur er Leverkühn imidlertid gennemsyret af Bertrams transcendensorienterede Nietzsche-myte. Ad den vej ender romanen i syndefaldsstemning og vor remytologiseringshelt Leverkühn i det skyldstyngende moderskød, han aldrig afgørende har kunnet hæve sig fra. Udtrykkets rekonstruktion sker i den skyldiges lamento og ikke i "prangende hensynsløshed «.

Problematikken i Doktor Faustus udfolder sig så at sige som en dyst imellem tre grundlæggende indstillinger til spørgsmålet om menneskelig retfærdiggørelse: humanidealismen (retfærdiggørelse mulig og således påkrævet), nietzscheansk vitalisme (retfærdiggørelse ikke mulig og heller ikke påkrævet) og kristen syndefaldserfaring (retfærdiggørelse ikke mulig, men påkrævet). Som filosofiske positioner får humanidealismen og vitalismen igennem hele romanen lov at gå i kødet på hinanden, men som fatalitet synes syndefaldserfaringen at få det sidste ord.

Billedet af Leverkühn i moderskødet lader sig udmærket udlægge som Tysklands nedsænkning i sumpen af anticivilisatorisk barbari. Men en sådan læsning må suppleres og udfordres af en udlægning, der i moderens favntag 
ser en syndsbevidsthed, hvis desperation viser sig i den kristne perversion, som djævelske repræsenterer i Doktor Faustus. Interessen rettes imod faldsstemningen, ikke som udtryk for en dom over den nietzscheanske remytologisering, men som symptom på, at den nietzscheanske stræben efter suverænitet - som det er tilfældet hos Bertram - er flettet sammen med og stækket af en luthersk kristendom og dennes syndsbevidsthed - med andre ord som et symptom på Leverkühns moderbinding. Når Doktor Faustus på den måde læses som en problematisering af Bertrams Nietzsche-myte, betyder det ikke blot en modificering af den Nietzsche-kritik, romanen umiddelbart lægger op til. Det kan ligefrem blive relevant at mobilisere Nietzsche selv i problematiseringen af den bertramske djævleforskrivelse. ${ }^{24}$ Når romanen installerer denne djævleforskrivelse som baggrund for den tyske katastrofe, antydes således en diagnose, som sigter til en sygelig syndsbevidsthed - en manglende evne til at opstille, bejae og forbruge suveræne kulturelle værdier på grund af orienteringen imod en bebrejdende transcendens.

Følger man den vitalistiske remytologiseringsbestræbelses skæbne - Leverkühns fald i kraft af moderbindingen - fremtræder Doktor Faustus altså som en begrædelse af suverænitetens umulighed snarere end en fordømmelse af dens kontroversialitet i forhold til en i sig selv problematisk civilisatorisk indstilling. På den baggrund må man revidere opfattelsen af Doktor Faustus som et opgør med Betrachtungens kulturaristokratiske indstilling, et opgør svarende til det man finder i det sene Nietzsche-essay og i 'Deutschland und die Deutschen'. Disse velmenende, men noget snævrere perspektiverede ytringer mister hurtigt pusten konfronteret med romanens indsigter. Det vil efter meget at dømme være klogere at tilslutte sig Eric Heller, der i The Ironic German efter sin behandling af Betrachtungens nietzscheanske kulturanalyse konstaterer at »en dag skulle Thomas Mann i Doktor Faustus igen sammenfatte kunstens og politikkens skæbne, en genoplivelse ... i den selvsamme stemning som var Betrachtungens - denne gang på tærsklen til helvede. ${ }^{25}$

Den unge Manns upolitiske position må ikke, som f.eks Bernhard Böschenstein er tilbøjelig til, forveksles med Bertrams lutherske inderlighed. Når den unge Mann angriber civilisationslitteratens transcendenorientering »den frygtelige negativitet hos frihedens intellektuelle bannerførere ${ }^{26}{ }^{2}$ - sker det ikke i tilslutning til den negativitet, hvormed den bertramske helt må fornægte den kulturelle inkarnation. Betegnelsen upolitisk er først og fremmest polemisk rettet imod civilisationslitteratens politisering af det æstetiske og implicerer den nietzscheanske forestilling om, at det politiske i stedet skulle vokse ud af en kulturs æstetiske indforståethed med det dionysiske. ${ }^{27}$ En sådan forestilling kan være vanskelig at formulere i en offensiv tone efter nazismens forsøg på at æstetisere det politiske, men hvis det nazistiske projekts 
djævelske desperation netop beror på den forudgående afæstetisering af kulturen, skulle vanskeligheden helst ikke bevirke, at kritikken af denne kulturudvikling forstummer.

\section{Noter}

1. Friedrich Schiller kan tjene som eksempel på denne tidligere tyske idealismes optimisme. Netop Schillers optimisme - der også gælder kunstens potentiale - må være af særlig interesse for en læsning af Doktor Faustus, da det konkret er denne, der i og med Beethovens 9. symfoni 'tages tilbage' af Leverkühn i kap. 45.

2. Manfred Frank: Gott im Exil, Frankfurt a.M. 1988, pp. 339-40 (herefter forkortet GIE).

3. Dette lille manifest blev udgivet i 1796, så vidt vides af de tre værelseskammerater: Hegel, Schelling og Hölderlin.

4. Thomas Mann: Doktor Faustus, Stockholm 1947, p. 84 (herefter forkortet DF). Hvor andet ikke anføres bruges Mogens Boisens oversættelse, Kbh, 1992.

5. DF, p. 326, min oversættelse

6. DF, p. 320, min oversættelse.

7. Friedrich Nietzsche: Die Geburt der Tragödie, Berlin/New York, 1967ff.(herefter forkortet $G T$ ). Hvor andet ikke anføres bruges Isak Winkel Holms oversættelse, Kbh. 1996

8. DF, p. 326, min oversættelse.

9. Friedrich Nietzsche: Zur Genealogie der Moral, Stuttgart, 1988, p. 79.

10. Efterlysningen af en mytisk orden kan således sagtens, som ren konservatisme og nationalnostalgi, være udtryk for alt andet end en indforståethed med illusionsvitalismens dynamiske præmis.

11. Når Manfred Frank ikke selv gør sig til talsmand for den simple fordømmelse af Leverkühns projekt, hænger det bl.a. sammen med hans læsning af fortæller Zeitbloms rolle i romanen - udlægningen af Leverkühnfiguren som biografens fantasifoster - der i stedet fører til interessante formuleringer om det ciliviliserede menneskes behov for myten om den dæmoniske kunstner og et forbandet Tyskland, samt til et forsvar for kunstneren ud fra en Adorno-inspireret hævdelse af kunstens negativitet.

12. Bernhard Böschenstein: "Ernst Bertrams Nietzsche - eine Quelle für Thomas Manns Doktor Faustus«,in Euphorion 72 (1978), p. 70.

13. Bertram citerer fra Nietzsches efterladte papirer. Ernst Bertram: Nietzsche - Versuch eine Mythologie, Berlin, 1929 p.118 (herefter forkortet NVM).

14. Disse den tyske reformationsånds to store helte gennemsyrer således den senmiddelalderlige stemning, der bl.a. knytter sig til Kaisersaschern, hvor den unge Leverkühn først inddrages i musikkens verden. På et formelt plan etablerer romanen desuden en kobling til Dürer, idet den lader adskillige af hans stik fungere som model for sine beskrivelser, især af Leverkühns familie og omgivelser, ligesom Leverkühn selv bruger Dürer som forlæg til sit værk 'Apocalipsis cum figuris', jfr. Volker C. Dörr: »Apocalipsis cum Figuris«, Zeitschrift für Deutsche Philologie 112 (1993). Hvad angår identifikationen med Luther, kan der peges på, hvorledes Leverkühn fremstilles som munk, og på parallelen imellem hhv. Luthers og Lever- 
kühns møde med djævelen.

15. Det bliver mere og mere tiltrængt at pege på romanens tematisering af Søren Kierkegaard, hvis mytografi ligesom Nietzsches har en central placering i materialet til Leverkühn-figuren. Kierkegaard kunne med fordel tematiseres ud fra begreber som transcendenserfaring, inderlighed og protestantisk heroisme - uden dermed umodificeret at skulle identificeres med Bertram.

16. I denne omtale af det allegoriske henholder jeg mig til Walter Benjamins allegoribegreb, sådan som det udfoldes i Ursprung des deutsches Trauerspiels. Allegorien knyttes her til den historiske baroks syndefaldserfaring. For barokkens melankolske blik fremtræder verden som falden: døden står skrevet $\mathrm{i}$ alt historisk, og enhver betydning er konventionel og arbitrær, sådan som emblemteksten demonsterer det barokke emblems konventionalitet. Det allegoriske værk karakteriseres på den baggrund ved allegoristens almagt i konstellationsarbejdet med et meningstomt materiale. Herved kan det allegoriske minde om den konstruktivisme, jeg har karakteriseret ved en vis arbitraritet i formgivningen. Det allegoriske placerer sig imidlertid i modsætning til tilstræbelsen af en suveræn konstruktivisme. Ligesom det er tilfældet med mystikkens konstellationsarbejde, som Benjamins tankegang er præget af, forbliver allegoriens betydningsdynamik nemlig inden for transcendensorienteringens rammer, således at den i længden "genfinder sig selv, ikke længere legende i den jordbundne tingsverden, men alvorsfuld under himlen. "Allegorien vil ikke ignorere retfærdiggørelsesproblemet, men snarere, ligesom parodien, fremvise betydningernes gudsforladthed, for ved en subtil dialektik at slå bro til en frelseshorisont, og således »udfylde og fornægte det Intet, hvori de præsenterer sig, ligesom intentionen i sidste ende ikke trofast fastholder betragtningen af knogler, men forrædderisk springer over til opstandelsen«, Walter Benjamin, Ursprung des deutschen Trauerspiels, Frankfurt a.M. 1955, p. 208.

17. Erfaringen af det uendelige tomrum, der med faldsstemningen synes at adskille menneske og Gud, viser sig ligeledes i Leverkühns interesse for det kosmisk uendelige, hvorom en lille diskussion udspiller sig i kap. 27. I Zeitbloms indvendinger skimtes en forståelse af sammenhængen imellem arbitraritetserfaring og transcendenserfaring: »[...] kan en konstruktion overhovedet betegnes som Guds gerning, når man lige så godt kan sige »Og hvad så?« som »Hosianna« til den? [...] Jeg kan ikke se nogen som helst grund til at kaste sig tilbedende i støvet for qvinqvillionen« (DF, p. 365).

18. $D F$, pp. 649-50, min oversættelse.

19. Adskillige barokke karaktertræk kunne påpeges, ligesom det allegoriske ved værkets angivelige opsummering af musikkens stilhistorie ( $D F$, p. 646).

20. Dette lutherske træk fremhæves af djævelen selv i kap. 25, idet han refererer til den reformatoriske forkastelse af boden til fordel for totalangeren ( $D F$, p. 333).

21. DF, p.669, min oversættelse.

22. Den jødiske impressario Fitelberg kommer i kap. 37 med grove hentydninger til en tysk moderbinding hos Leverkühn.

23. Eller den gådefulde "menneskelige forståelse« som Fru Schweigestill med bogens sidste replik lancerer som et alternativ til »den evige nåde«, men som måske ikke er mindre befængt med moderfatalitet ( $D F$, p. 665).

24. Georges Bataille har-ikke mindst i La Part Maudite, hvor han explicit diskuterer Doktor Faustus - udfoldet en neitzscheansk kulturkritik med et vist forklaringspotentiale i forhold til Leverkühns og Tysklands skæbne.

25. Erich Heller: The Ironic German, London 1958, p. 131. 
26. Op.cit., p. 130.

27. Omend Mann med sit begreb om »Bürgerlichkeit« står for en mere realistisk - eller rettere ironisk - vitalisme end Nietzsches, dvs. en vilje til at bejae de borgelige værdiers fakticitet, selv om de formentlig ikke besidder den prometheiske udstråling, som Nietzsche har set for sig. Denne forskel genfindes i det sene Nietzscheessay, hvor Mann kritiserer Nietzsches tænkning for at være upragmatisk. Nietzsches kompromisløshed risikerer at gøre hans vitalisme til en ny orientering imod transcendensen. Af den grund, om ikke andet, bør Bertrams indlæsning af Nietzsche i den tyske 'Sehnsucht'-tradition ikke fejes helt af bordet. Også den vitalistiske fokusering på den »mytiske hjemstavn« $(G T$, p. 154) lader sig jævnføre med Leverkühns skæbnesvangre moderbinding. 